\title{
Mapping long-term retail trends in London
}

Received (in revised form): 2nd February, 2005

\section{Mark Thurstain-Goodwin}

read geography at Girton College, Cambridge and after working as a commercial property analyst for four years, took a Master's degree in Geographical Information Systems (GIS) at University College London (UCL). He now runs Geofutures, a strategic consultancy specialising in complex data analysis and Gl science. As well as running Geofutures, Mark also retains a close working association with UCL, where he is a visiting research fellow at the Centre for Advanced Spatial Analysis, funded by the David Thorpe Research Fund.

\section{Yi Gong}

has a background in Information Engineering and Geography. She is researching agent-based simulation models for her PhD at the Centre of Advanced Spatial Analysis at UCL.

\begin{abstract}
The changes in the retail economy since the 1960s and 1970s have been immense. And while the general shape and form of these changes are widely agreed, actual quantification of these changes is limited. This paper outlines how the last UK Census of Distribution (in 1971) was digitised in order to facilitate comparison with the Office of the Deputy Prime Minister's (ODPM's) town centres statistics set which was the first attempt to monitor the retail sector for three decades. The challenges of matching these two data sets, both in terms of their spatial definition and retail classification system, are explored. Some early analysis showing how retailing has changed in Greater London is also presented.
\end{abstract}

Mark Thurstain-Goodwin Geofutures Ltd, The Ice House, 124-126 Walcot Street, Bath BA1 5BG, UK.

Tel: +44 (0) 1225338 222; Fax: +44 (0) 1225332 555; e-mail:

mtg@geofutures.com

\section{INTRODUCTION}

Retailing is highly significant to London's employment, economy, tourism and inward investment. The London Retail Sales Monitor, published by London Retail Consortium with KPMG, estimated that more than 356,000 people were employed in retail in the capital in September 2003. This represented around 9 per cent of the total workforce. It goes on to estimate that there are more than 30,000 shops in London, 3,000 of them in central London, and that the retail and wholesale industries contribute 13 per cent of the city's gross domestic product (GDP). ${ }^{1}$

Until May 2004 no one could assess the accuracy of these estimates. Then the
Office of the Deputy Prime Minister (ODPM) published a range of retail statistics, dated to 2000 , offering a reliable picture of the performance of the retail economy. ${ }^{2}$ This was the result of a programme of research through which a model was developed capable of manipulating existing sources of government data used to track employment, turnover and commercial floorspace into meaningful aggregations of town centre statistics. ${ }^{3,4}$

Prior to this, the last systematic collection of data about retail activity in London or the UK as a whole was in 1971. The 1971 figures were the result of the last in a series of Censuses of Distribution and Other Services, taken in 
1950, 1957, 1961, 1966 and 1971, which drew a comprehensive picture of retailing in Britain over this period. The last full census in 1971 provided volumes of data on shopping areas in towns of more than 50,000 across the country, and for the capital it covered each London Borough, the City, and the other towns in the region having a population of 20,000 or more. $^{5}$

University College London's (UCL's) Centre for Advanced Spatial Analysis have undertaken the task of linking the 1971 Census of Distribution with the ODPM town centres data released in 2004. The purpose of this project, sponsored by GLA Economics, was to provide a means of measuring the changes which have affected Greater London's retail economy during the 30 years since the last systematic survey of retailing in the capital was undertaken.

A number of significant issues had to be overcome while attempting this comparison, the greatest of which being that the 1971 data were held only in hard copy format. Geographical changes to London's town centres and the definitions applied in the two data sets also presented challenges. This paper details the methods used to address these difficulties and sets out the results of some initial analysis.

\section{PLACE NAMES - A MEANS OF LINKING THE DATA SETS}

The two data sets are very different and reflect the differences between the analytical eras that spawned them. Not only was the structure of the retail economy completely different in 1971, but the tools used to analyse retailing were much more basic. The 1971 Census data for London comprise a series of hard copy data tables in which a range of indicators is presented for the city's 33 Boroughs and 104 town centre shopping areas.
These aggregate totals give details of the number of shops and total floorspace dedicated to a particular retail activity (such as the sale of furniture) as well as the sector turnover and number of people employed and their normal hours worked in a week. Information about the type of retail business engaged in an activity - independent, multiple or co-op - is additionally given.

The 2000 data series does not currently offer such a detailed breakdown of the retail economy. Retail employment is only coarsely disaggregated into convenience, comparison and service categories and although it gives the total number of persons employed (which is directly comparable to the 1971 Census) it does not, at present, make a distinction between part-time and full-time employees. A total retail floorspace figure is available at the district and town centre level although, as will be discussed later, this does not accord with the floorspace definition of the earlier Census.

Nevertheless, the data held within the tables can be compared, to a greater or lesser degree. The next problem is more intractable - do the definitions of the town centre shopping areas in the 1971 Census bear comparison to those of the 2000 series? An obvious way to check would be to examine the geographical extent of the areas for which the statistics were collected.

While this is a simple task for the later series, there were no maps showing the spatial extent of town centre shopping published in the main volumes of the 1971 Census. The only way in which town centres in both series can begin to be matched is by place name and, as is discussed later, this is not necessarily straightforward.

The absence of geographical extents means that it is necessary to consider 
the way in which town centres have been defined over the last half a century. Josep Lluis Sert, ${ }^{6}$ former Professor of Architecture at Harvard University, looked at the focal points of transport systems and the communities they served, as a means of identifying them, while American geographers Murphy and Vance ${ }^{7}$ classically looked for concentrations of a series of factors including retail and office premises and high land values. It is likely that the 1971 Census concentrated on the main retail pitch in its definition although it is not certain if secondary or more peripheral streets were included. It is not even certain that a consistent method of defining them was applied across the whole capital or if a more subjective approach was used.

Regardless, it is important to recognise what unifies these and other methods (including the definition methodology of the new ODPM series): ${ }^{8}$ town centres are represented as objects in geographic space. Town centres are thus almost archetypal examples of geographic objects with indeterminate boundaries. ${ }^{9}$ The implication is that the boundaries of town centres are an attribute of them, rather than defining them.

In effect, this means that the geographic aspect of the town centre (the boundary) can be subordinated to the place name. While Tottenham town centre will have changed significantly between 1971 and 2000, both in terms of its retail mix and its geographic extent, it nevertheless remains Tottenham town centre. This means that to some degree, comparisons can be made between town centre aggregation totals in both series. (This does not present a problem when comparing Borough-level data though since their boundaries have hardly changed, if at all, in the past 30 years).

\section{CREATING A DIGITAL 1971 CENSUS OF DISTRIBUTION}

ODPM's town centre statistics for 2000

are available in a variety of different digital formats, but the 1971 Census exists only in hard copy. The first phase of this operation involved digitally encoding the 1971 data.

The volume containing data for Greater London and the South East was scanned using optical character recognition (OCR) technology. In OCR processing, the scanned-in image or bitmap is analysed for light and dark areas in order to identify each alphabetic letter or numeric digit. When a character is recognised, it is converted into an ASCII code. This ASCII code can then be transferred into an Excel spreadsheet for storage and analysis.

The formatting of data in the resulting spreadsheet exactly matches that of the hard copy (Figure 1).

Once the digitised data have been checked for scanning errors, it was necessary to translate the data from the old table structure which was preserved when the data were converted into Excel.

In order to facilitate comparison with the ODPM statistical series, the data had to be able to be queried into a more flexible flat-file, whereby each individual Greater London District and town centre comprised a row in the table with attribute information stored in columns.

The transfer of the data from the 230 Excel spreadsheets into a single database in readiness for linkage with the 2000 town centres data was not simply a matter of transferring data from cells to data tables. There were a number of additional issues that needed to be overcome.

These issues could be broadly grouped into the following categories:

— matching the names; 


\begin{tabular}{|c|c|c|c|c|c|c|c|c|c|c|c|c|}
\hline TABLE 9B (continued) & & & & & & & & & & \multicolumn{3}{|c|}{ London } \\
\hline & & & & & & & & & & & & \\
\hline \multirow{5}{*}{80} & \multicolumn{7}{|c|}{ 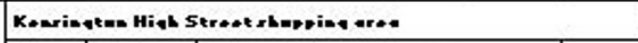 } & \multicolumn{5}{|c|}{ Kantirb Tmua rbmpries ere. } \\
\hline & \multirow{3}{*}{ Shopr } & \multirow{3}{*}{ Turnaver } & \multicolumn{4}{|c|}{ Porrons engaged } & & & & \multicolumn{3}{|c|}{ Ferransengaged } \\
\hline & & & \multirow[b]{2}{*}{ Tatal } & \multicolumn{3}{|c|}{ Narmal haurs uarked in uoek } & \multirow[b]{2}{*}{$\begin{array}{l}\text { Flaor } \\
\text { spase }\end{array}$} & \multirow[b]{2}{*}{ Shops } & \multirow[b]{2}{*}{ Turnaver } & \multirow[b]{2}{*}{ Tatal } & \multicolumn{2}{|c|}{ Narmal haurs uark } \\
\hline & & & & Over 30 & $\begin{array}{l}\text { Over \$ } \\
\text { and up } \\
\text { to } 30\end{array}$ & $\begin{array}{c}\text { Nat mars } \\
\text { thans }\end{array}$ & & & & & Over 30 & $\begin{array}{l}\text { Over } 8 \\
\text { ond up } \\
\text { to } 30\end{array}$ \\
\hline & Number & $t^{\prime} 000$ & Number & Number & Number & Number & Sq.ft. & Number & $t^{\prime} 000$ & Number & Number & Number \\
\hline TOTAL RETAIL SHOPS & 215 & 24.709 & 4.206 & 2.529 & $1.15 \bullet$ & 527 & 790 & 117 & $5.1 * 3$ & $67 *$ & 459 & 153 \\
\hline 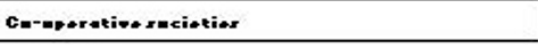 & - & - & - & - & - & - & - & \multirow{2}{*}{36} & \multirow{2}{*}{3.122} & \multirow{2}{*}{366} & \multirow{2}{*}{224} & \multirow{2}{*}{97} \\
\hline Multiplax & $\neq 7$ &. \pm \pm 12 & 974 & 543 & $27 *$ & 153 & 157 & & & & & \\
\hline Iodependenter & $12 *$ & $15 . * 97$ & 3.232 & $1.9 * 6$ & $\neq 72$ & 374 & 632 & $* 1$ & $2.06 \bullet$ & 312 & 235 & 56 \\
\hline Grmeers aed previrime deterr & 12 & 1.936 & 144 & 90 & 31 & 23 & 19 & 12 & 1.797 & 174 & 112 & s9 \\
\hline Oeber fend reteilers & 15 & 947 & 71 & 49 & $2 \bullet$ & 2 & 6 & 13 & 403 & s* & $3 \bullet$ & $1 *$ \\
\hline Dairymen & $\cdot$ & $\cdot$ & $\cdot$ & $\cdot$ & $\cdot$ & $\cdot$ & $\dot{-}$ & - & - & - & - & - \\
\hline Butehers & $\cdot$ & $\cdot$ & 20 & c & $\cdot \dot{2}$ & 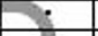 & $\cdot$ & 4 & 139 & 20 & 16 & 3 \\
\hline Firhmonqers, paulterers & $\cdot$ & 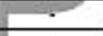 & 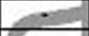 & 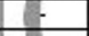 & -1 & - & - & 3 & 62 & 10 & 6 & 4 \\
\hline Greongrasers, fruiterers (insluding thareselling firh) & $\cdot$ & $\cdot$ & $\cdot$ & 2 & $\cdot$ & 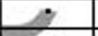 & $\cdot$ & 3 & 33 & 5 & 3 & 2 \\
\hline Eroad and flour sonfestioners & $\cdot$ & $\cdot$ & $\div$ & $\therefore$ & $\cdot$ & $\cdot$ & $\cdot$ & $\cdot$ & $\cdot$ & $\cdot$ & $\cdot$ & $\cdot$ \\
\hline Off-lisencer & 8 & 571 & 26 & 20 & 5 & 1 & 3 & $\cdot$ & $\cdot$ & $\cdot$ & $\cdot$ & $\cdot$ \\
\hline 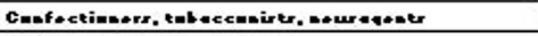 & 17 & $4 \$ 6$ & 62 & 39 & 19 & 4 & 5 & 10 & 297 & 36 & 19 & $*$ \\
\hline Clathied esd fmetucer shmpr & 90 & 4.930 & $63 *$ & 394 & 164 & $\neq \bullet$ & 113 & 33 & 991 & $16 *$ & 99 & $3 *$ \\
\hline Faotucarshaps & 16 & 934 & 137 & 76 & 21 & 40 & 24 & 7 & 127 & 25 & 15 & 3 \\
\hline Men's and bays' wearshops & 20 & 926 & 94 & 73 & 13 & 8 & 21 & $\$$ & 183 & 30 & 21 & 5 \\
\hline $\begin{array}{l}\text { Wamen's and airle' vear, haurehald textiler and aeneral slathing } \\
\text { shops }\end{array}$ & 54 & 3,070 & 407 & 245 & 130 & 32 & 68 & 18 & $6 \$ 1$ & 113 & 63 & 30 \\
\hline Herrabeld quedr shepr & 41 & 1.455 & $16 *$ & 11* & 29 & 13 & 44 & 24 & $\leqslant 49$ & 116 & 96 & 15 \\
\hline Furniture and alliedshops & 23 & 961 & $\$ 3$ & 62 & 16 & 5 & 33 & 9 & 500 & 67 & 56 & 8 \\
\hline Radia andelestrieal quadrshoper (exeluding hire) & \multirow{2}{*}{9} & \multirow{2}{*}{278} & \multirow{2}{*}{42} & \multirow{2}{*}{32} & 8 & 2 & 5 & 4 & 224 & 35 & 24 & 5 \\
\hline Radia and televirion hiroshops & & & & & & & 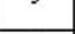 & . & . & 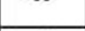 & 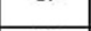 & \\
\hline Harduare, ehina, uallpapor and paintshops & 9 & 215 & 35 & 24 & 5 & 6 & 5 & 6 & 126 & 14 & 11 & 2 \\
\hline Oether ano-fand reteilers & - & - & - & - & - & - & - & - & - & - & - & - \\
\hline Boakshops andrtationers & 9 & 721 & 97 & 39 & 41 & 17 & 10 & 3 & 50 & 7 & 6 & 1 \\
\hline Chemires, phatoagrophic doalers & 9 & 703 & 75 & 57 & 7 & 11 & 5 & 4 & 160 & 17 & 17 & $\cdot$ \\
\hline Cyelesedperambulatarshops & - & $\cdot$ & - & $\cdot$ & - & - & - & $\cdot$ & $\cdot$ & $\cdot$ & $\cdot$ & $\cdot$ \\
\hline Jouellery, leather andrpares a a dreshops & 15 & 703 & 73 & 52 & 13 & 8 & 13 & 11 & 291 & 42 & 38 & 2 \\
\hline Other non-faodshops & $\cdot$ & $\cdot$ & $\cdot$ & $\cdot$ & $\cdot$ & $\cdot$ & $\cdot$ & 3 & 57 & 15 & 11 & 4 \\
\hline Genereleteres & - & - & - & - & - & - & - & - & - & - & - & - \\
\hline Departmentstaros & $\cdot$ & $\cdot$ & $\cdot$ & $\cdot$ & $\cdot$ & $\cdot$ & $\cdot$ & $\cdot$ & - & - & - & - \\
\hline Varieky and qeneral haurehaldstares & $\cdot$ & $\cdot$ & $\cdot$ & $\cdot$ & $\cdot$ & $\cdot$ & $\cdot$ & $\cdot$ & $\cdot$ & $\cdot$ & $\cdot$ & $\cdot$ \\
\hline
\end{tabular}

Figure 1 An example of a table from the Census of Distribution in Excel format

- matching the descriptions of the retail economy;

- differences in floorspace data;

- handling data disclosure.

\section{Matching the names}

The two data sets were linked by the names of the town centres, and the names of the districts in which they are located. No problems were encountered matching the names of the district summaries in the 1971 and 2000 data sets: the names of London's 33 Boroughs are set out in statute and have not changed for many years. The naming of town centres proved more problematic, since these names are not officially defined.

Of the 104 town centres defined in the 1971 Census of Distribution, only 100 could be matched. The four town centres present in the 1971 series but not in the 2000 data were Manor Park, Shepherd's Bush, Sidcup Station Road and Whitton. Furthermore, it was not possible to exactly match the names of 25 town centres although on the whole 
Table 1: 1971 Census of Distribution convenience and comparison retail aggregations

\begin{tabular}{ll}
\hline Convenience retail & Comparison retail \\
\hline Grocers and provision dealers & Clothing and footwear shops \\
Other food retailers & Household goods shops \\
Confectioners, tobacconists, newsagents & General stores \\
Chemists, photographic dealers & Other non-food retailers \\
& Bookshops and stationers \\
& Cycle and perambulator shops \\
& Jewellery, leather and sports goods shops \\
& Other non-food shops \\
\hline
\end{tabular}

a one-to-one matching exercise was feasible. In the case of Ealing, however, the 1971 Census of Distribution defined two distinct town centres - West Ealing and Ealing Broadway — which are merged in the 2000 series.

\section{Matching the descriptions of the retail economy}

Once the town centres in both series had been matched, it was necessary to ensure that the statistics recorded for each town centre in both series were comparable. The 2000 series divided the retail economy into three components: ${ }^{10}$

- convenience retailing;

- comparison retailing;

- service retail.

The 1971 Census of Distribution does not aggregate retail information into the same categorisations. It should not be a surprise to see such a difference, given the structural changes that have affected the sector since then. For example, few people now purchase fruit and vegetables from a greengrocer, or wait for a butcher to slice bacon, preferring instead the perceived convenience of the supermarket. Retailing is now often considered as a leisure activity with service retailers such as travel agents and video rental stores being a core part of the retail experience. It is interesting to note that in 1971, only hairdressers were identified as part of the service retail economy.

The definitions of convenience and comparison retail have also changed to an extent. The more detailed retail classifications of the 1971 Census of Distribution have therefore been aggregated in the way shown in Table 1.

On the whole, it was possible to match the retail categories of the 1971 Census of Distribution with those of the 2000 series, with the exception of 'Chemists and photographic dealers'.

In the 1971 series, chemists and photographic dealers were viewed as comparison retailers, whereas in the 2000 series, chemists are classified as convenience retailers (photographic dealers remain classed as comparison retail).

This presented a problem, since while there was no way to subdivide chemists from photographic dealers in the 1971 series, the two are far more distinct on today's high street. Chemists and photographic dealers have therefore been classified as convenience retail to enable the data sets to be compared. Of course this means that convenience retail in 1971 is being over-counted while at the same time comparison retailing is under-counted. The authors would argue, however, that in 1971 photographic dealers did not play a huge role in the retail economy and thus the potential for error is probably quite small. 


\section{Floorspace data}

The floorspace of retail establishments was measured differently in 1971 and 2000. Not only had the 1971 floorspace data to be converted from square feet to square metres to match the 2000 data set, which was readily done, but also retail floorspace itself was defined differently in the two data series.

The 1971 Census of Distribution defined retail floorspace as being:

'confined to that used for selling and display only. It is defined as that area used for selling to customers, including the space to which customers have access, counter space, window and other display space, fitting rooms and space immediately behind counters used by shop assistants. It excludes offices, storage and preparation rooms, work rooms, lobbies, staircases, cloakrooms, and other amenity rooms'.

Whereas the 2000 definition uses the Valuation Office Agency's (VOA's) definition of retail floorspace: that which

'serves the public "off the street". The class includes (but is not confined to) banks, building society outlets, betting shops, hairdressers and beauty salons, pharmacists, launderettes and dry cleaners, post offices, real estate agents, tax consultants, travel agents, ticket sales, takeaways bars, restaurants, cafes, wine bars, food courts, amusement arcades, showrooms, hyper markets, retail warehouses, superstores and department stores. Also included are markets, car sales showrooms and sales yards, shops selling car parts, farm and factory shops, hobby shops, kiosks, booths, photo booths, craft workshops that display and sell goods and street front repair shops. Some health centres may be valued as retail. The bulk class includes some wholesale premises (others are typically warehouses)'.

This presents a significant problem since the former type of space will always be smaller than the latter for two key reasons. First, the VOA's definition of retail floorspace includes financial and business services as well as food and drink outlets, establishments not included in the 1971 Census. This problem can be circumvented to some degree by comparing the census data with the A1 floorspace totals included in the 2000 series. It must be borne in mind that this category not only includes floorspace not explicitly included in the 1971 Census (such as post offices), but also that the A1 total is an estimate derived from the VOA data set. The second issue concerns the definition of space within retail units. The floorspace recorded in the 1971 Census comprises that used 'for selling and display only', whereas the 2000 definition includes other areas such as lobbies, staircase and storage areas. Ongoing research undertaken by UCL's Bartlett Graduate School suggests that ratio between the two is typically 0.63: 1 respectively. ${ }^{11}$

This factor has been applied across the full A1 data set, to attempt to derive a comparable indicator, although it is acknowledged that this is a simplification and that in some parts of the capital, the ratio of sales space to off-the-street area (which includes lobbies, staircases, cloakrooms and other amenity rooms) may be different.

\section{Data disclosure}

The final issue was that data for some retail classifications were not released in the 1971 Census of Distribution.

This occurred due to data disclosure restrictions. At the town centre scale, to release information (such as the number of employees employed in department stores, for example) might reveal confidential information about a particular business. On these occasions, the data aggregations were not released and the data were flagged as ' $\star$ '.

Without these data, the convenience and comparison retail aggregations could 


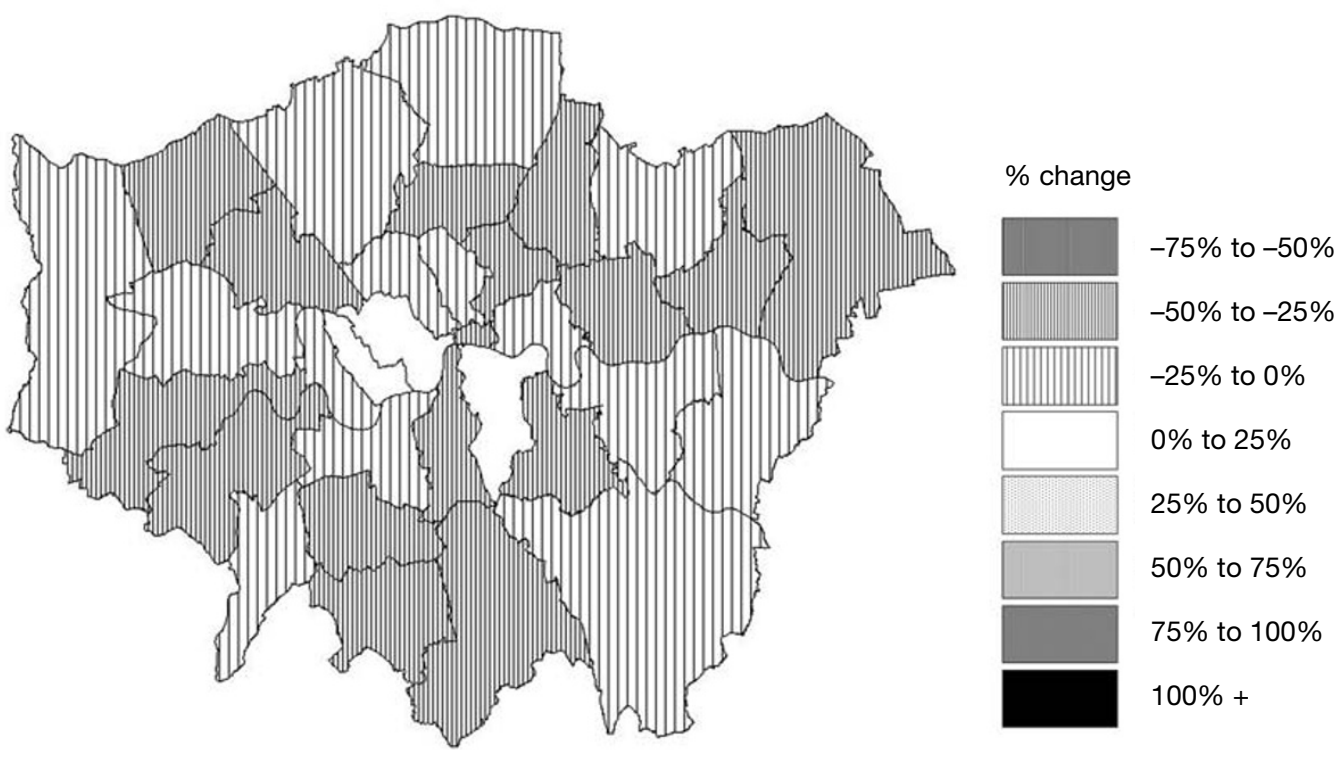

Figure 2 Percentage change in convenience retail employment 1971-2000 by district

be difficult to derive. In many instances, it was possible to create accurate aggregations using subtotals in the Census of Distribution tables, but for three town centres, Bexleyheath, Clapham Junction and Stratford, it was necessary to estimate the numbers for chemists and photographic dealers using Greater London averages. The percentages of total used were:

- 4.1 per cent for the number of shops;

- 4.6 per cent for turnover;

- 4.8 per cent for employment;

- 2.7 per cent for floorspace.

Using these it was possible directly to compare employment and floorspace totals for 33 London Boroughs and 100 town centres with those published for 2000 .

\section{CHANGES IN LONDON'S RETAIL ECONOMY BETWEEN 1971 AND 2000}

This section presents some initial findings of the changes that have occurred in
London's retail economy between 1971 and 2000. The data underpinning this analysis can be found on the CASA website. ${ }^{11}$

Three elements of the retail economy are considered in turn - convenience retail employment, comparison retail employment and retail floorspace - and how the patterns of retailing have changed at the district level and town centre level during this time will be examined.

\section{Convenience retail employment}

At the district level, it can be seen that with the exception of three Boroughs towards the centre of London, the number of people employed in convenience retail has fallen across Greater London (Figure 2). This would perhaps be expected since the food sector in particular has been consolidated by a small number of large retailers, the supermarket replacing the corner shop. Relative to the floorspace occupied, fewer people are required to run modern stores than the 


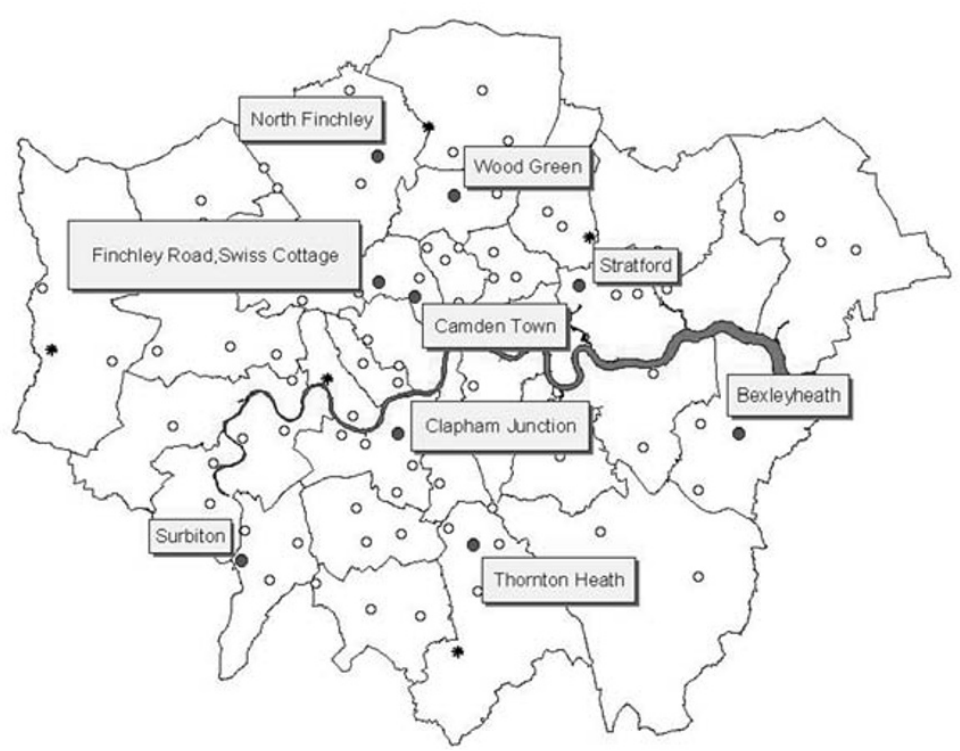

Figure 3 Ten best performing town centres, convenience retail employment 1971-2000 $*$ No data available

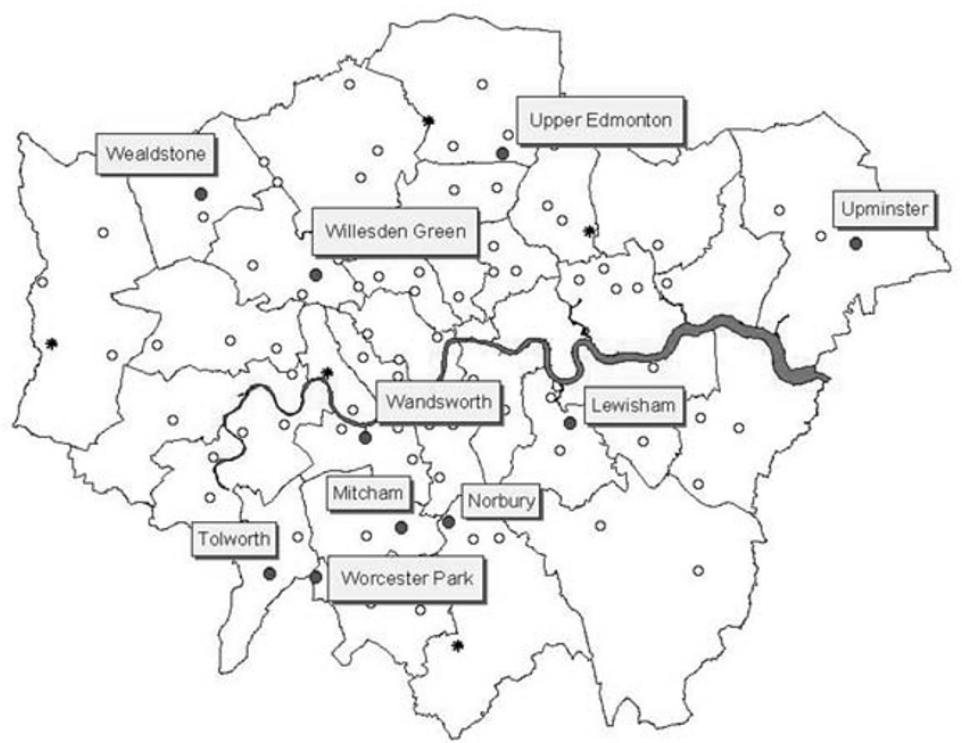

Figure 4 Ten worst performing town centres, convenience retail employment 1971-2000 * $=$ No data available

traditional food retailers of the 1960s and 1970s.

Trends expressed at the district level do tend to hide important local detail. In Figures 3 and 4 the ten best, and worst, performing centres in terms of convenience retail employment growth between 1971 and 2000 can be identified.
Figure 3 shows that there are a number of town centres where convenience employment has increased. Furthermore, none of these town centres fall within the three top Boroughs identified in Figure 2.

Stratford witnessed the biggest increase in convenience retailing between 1971 and 2000, employment growing by over 
500 per cent; Camden Town was next with an increase of over 200 per cent. In general, the trend has been one of decline in town centres. Of the 95 town centres which could be compared using this measure (five town centres had disclosive totals in the 2000 series and thus could not be compared) only 24 saw an increase between 1971 and 2000 . These growing centres are spread fairly evenly across Greater London in both central and peripheral locations suggesting that there were no macro level effects at work.

Looking at the distribution of the ten worst performing town centres (Figure 4), all of which have lost at least 78 per cent of convenience retail jobs, again there is no discernible spatial pattern relative to their locations within Greater London. This suggests that local factors are at work, which may include demographic changes in the immediate catchment populations, or indeed deterioration in the quality of the retail stock in these town centres.

It must also be considered that the 2000 data set may underestimate the number of people employed in the convenience retail sector, undercounting in the independent sector in particular. Nevertheless, it would have to be questioned whether undercounting could account for the 2,237 convenience job losses since 1971 in Hackney alone.

It is likely that the most important local trend at work is the decentralisation of food retailing away from town centres, neatly summarised by Schiller as the first phase of post-war retail development. Consumer demand for time-saving, car-accessible food shopping, coupled with retailers' own preference for easily-managed free-standing stores, gave rise to massive growth in out-of-town supermarkets in the 1970s. ${ }^{13}$

\section{Comparison retail employment}

The change in comparison retailing at the district level between 1971 and 2000 is more complex. Boroughs in the western half of the capital seem to have seen an increase in employment as do the City of London and the City of Westminster. In contrast, there is a wedge of eastern Boroughs which have seen a dramatic decline in comparison employment over this time (Figure 5).

The reasons for this are hard to disentangle. Schiller argued that comparison retailers followed the supermarkets to their suburban locations in the 1980s. Retail warehouse parks offered the same opportunities for maximum choice in the minimum time, and to offer so many lines the store had to be big. Shoppers now used to driving out of town to buy were the perfect target market for the third development phase in the 1990s: huge covered shopping malls in the Bluewater mould.

Yet in London there is limited space for retail warehouse development and certainly not for major shopping centres such as Lakeside Thurrock and Bluewater. This may be one reason why London's central shopping area has fared relatively well in competition with these two major developments, unlike other metropolitan centres like Sheffield or Bristol. London also further benefits from being a global tourist destination.

Thurrock is likely to be one reason why town centres in this eastern strip have suffered loss of comparison retail employment - Upper Edmonton, Leytonstone and Forest Gate are among the top ten worst performing town centres (Figure 7) although it may be due to the presence of available sites for retail warehousing.

It is a contention of many of the major retail warehouse retailers that London is undershopped and remains so because of the lack of large sites 


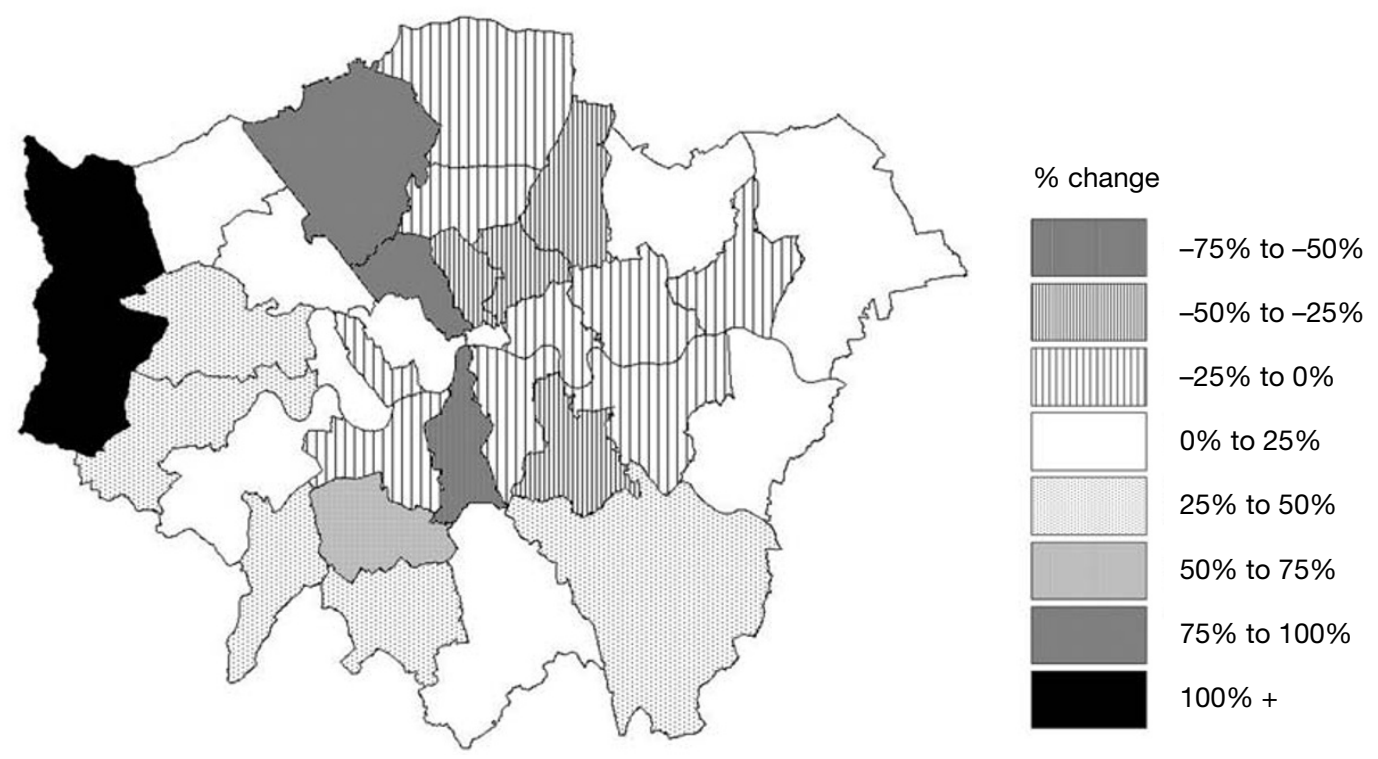

Figure 5 Percentage change in comparison retail employment 1971-2000 by district

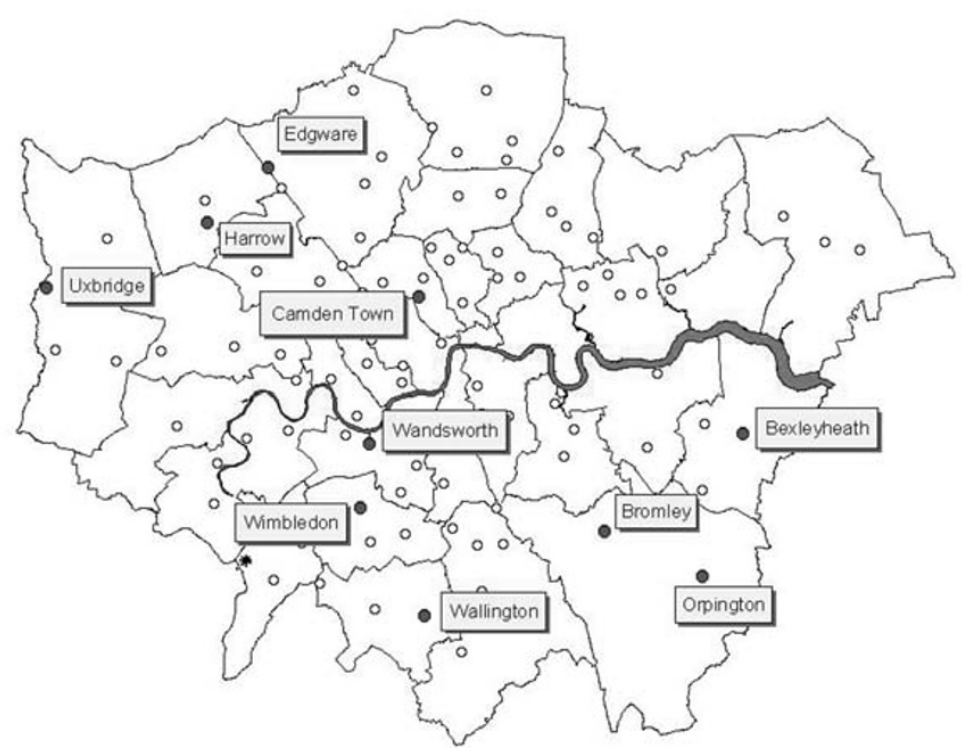

Figure 6 Ten best performing town centres, comparison retail employment 1971-2000 $*=$ No data available

suitable for this type of off-centre retailing. It is interesting to note in Figure 6 that with the exception of Wandsworth, there are no growing comparison retail town centres in any of the declining Boroughs identified in Figure 5. This may suggest that investment in comparison retailing in these Boroughs is moving away from traditional town centre locations.

In terms of the declining town centres, the pattern is less evident but there are three town centres which have suffered both significant comparison employment decline in addition to convenience retail decline. 


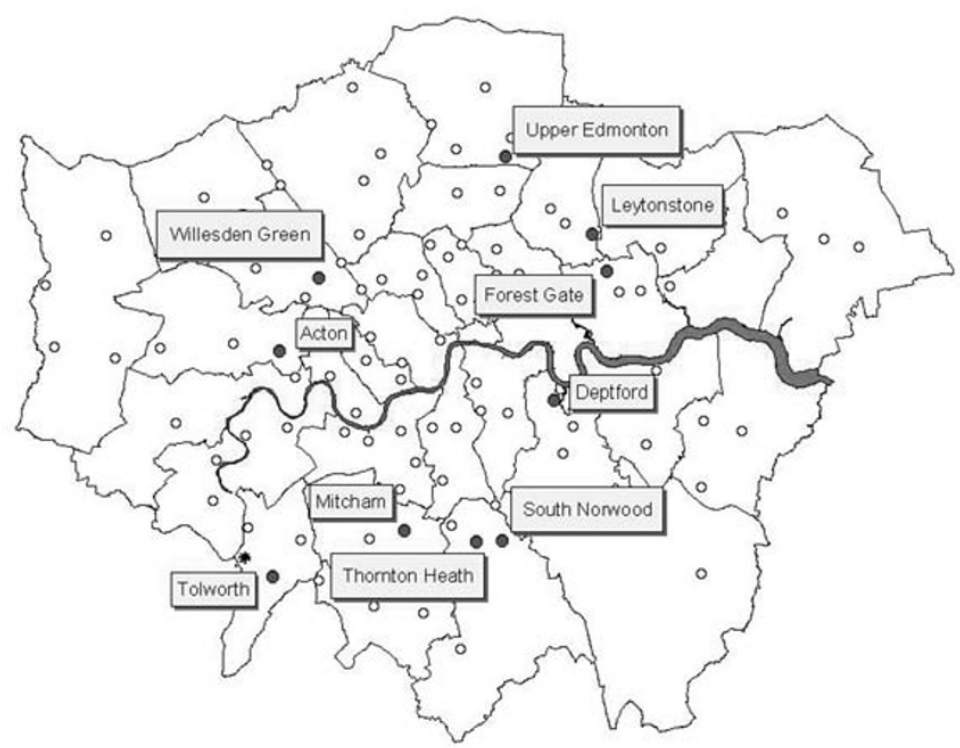

Figure 7 Ten worst performing town centres, comparison retail employment 1971-2000 * $=$ No data available
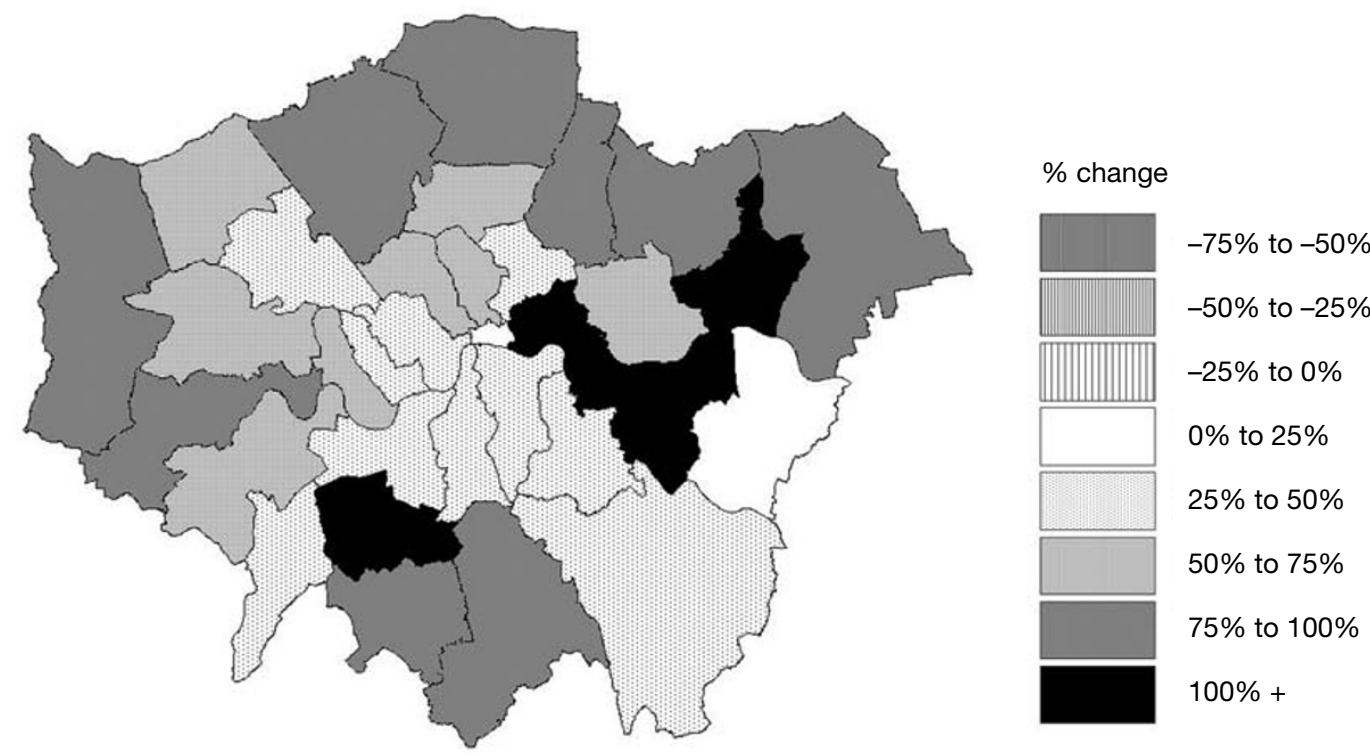

Figure 8 Percentage change in A1 floorspace 1971-2000 by district

Upper Edmonton saw a decline of 83 per cent in comparison retail employment while Mitcham and Tolworth saw a fall of 82 per cent and 81 per cent respectively. This suggests that there is a major structural failing in these town centres.

More investigation is needed to unpack these changes in the comparison retail economy in London. It would be interesting to look at the changes in the relative numbers of full and part-time employees for example, and also to look at the performance of certain categories of comparison retailing, such as department stores, in more detail. Presently the ODPM data set does not contain enough information to facilitate 


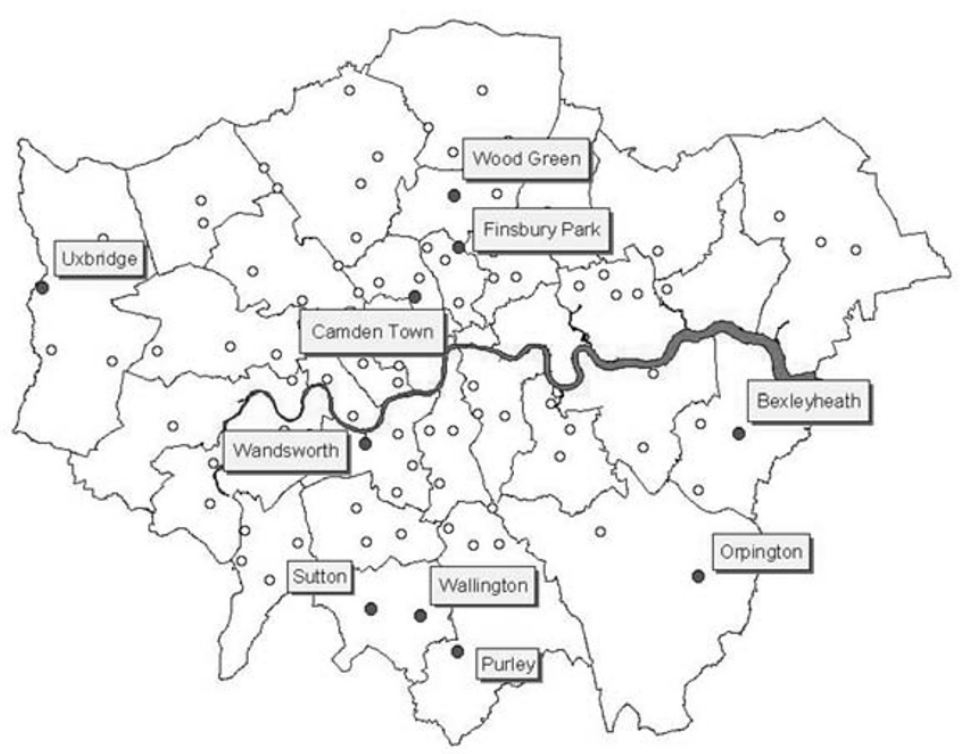

Figure 9 Ten best performing town centres, A1 floorspace 1971-2000

these comparisons but may do so in the future.

\section{Retail floorspace}

Assessing the changes in retail floorspace is more problematic (as mentioned above) because of the differences in the way in which retail floorspace is assessed in the 1971 and 2000 series. While it has been possible to apply a ratio to convert the 2000 A1 floorspace total to a net sales figure, care must be taken when interpreting the results since applying this ratio across all the London data will inevitably mask some variation.

What is immediately striking in Figure 8 , which uses the same percentage scale as the previous district maps, is that even when the sales area ratio is applied, all of London's Boroughs have seen an increase in the amount of $\mathrm{A} 1$ retail floorspace between 1971 and 2000. Of course, this map hides considerable variation within the districts themselves.

The ten town centres which have seen the biggest increase in retail floorspace have undergone an increase of at least 96 per cent (Wallington lies in tenth place at this level). Camden Town has seen the biggest increase of 185 per cent, arguably in line with its elevation to an international shopping destination in the 1980s and 1990s. ${ }^{14}$

Despite the rosy picture painted by the district map in Figure 8, 31 of the 100 town centres have undergone a fall in retail floorspace. The largest of these drops occurred in Willesden Green where 63 per cent of the A1 retail stock disappeared in the 30 years since the last Census of Distribution (possibly the result of competition from Brent Cross).

There were some surprising drops in the amount of floorspace in some central locations, most notably Knightsbridge (a fall of 47 per cent) and Kensington High Street (just outside the ten worst performers with a fall of 23 per cent).

On average, the amount of retail floorspace in London's main town centres increased by 26 per cent, suggesting that retailing has become more extensive in its space requirements. This is clearly one 


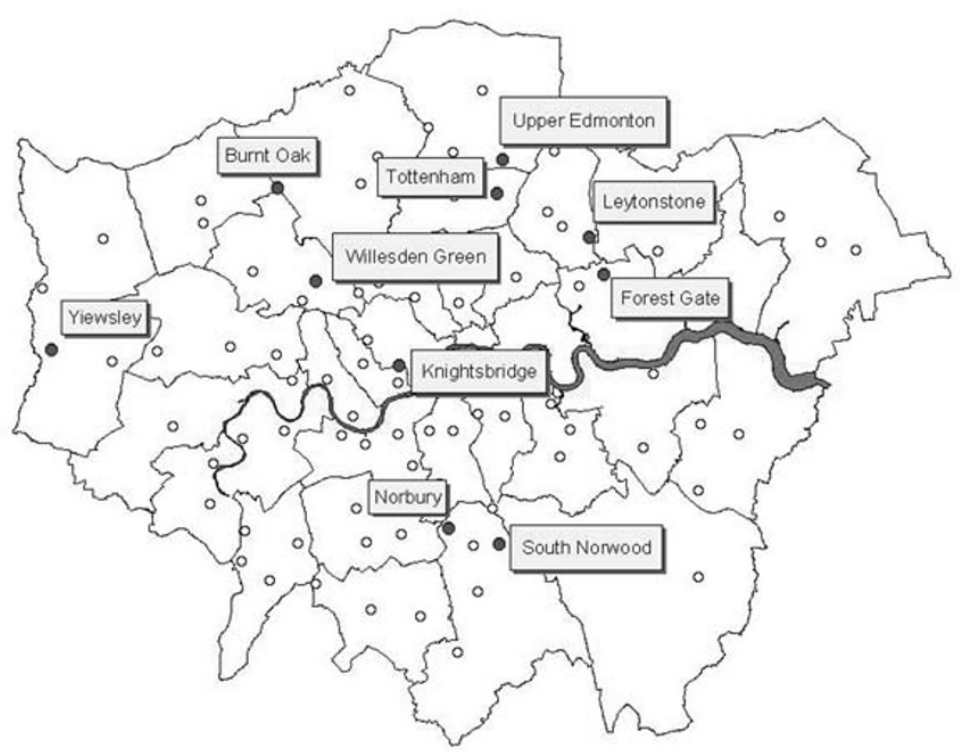

Figure 10 Ten worst performing town centres, retail A1 1971-2000

reason why retailing has moved to off-centre locations since the 1970s, but it is interesting that the town centres appear to have also grown during this period as well.

\section{CONCLUSION}

By linking the hard copy tables of the 1971 Census of Distribution to the digitally modelled statistics of the 2000 series it is possible finally to begin to quantify the huge changes that have occurred in retailing in the intervening decades.

Combining the two data sets was not straightforward. The lack of geographical information about the definition of the 1971 town centres meant that the data sets could only be matched by the name of the town centres, treating the boundaries as an attribute of the town centre, rather than the key defining element. Even when this was done, there were the problems of different definitions of the retail economy, as well as different methods for collecting the data, particularly with respect to floorspace.
Many of these problems could be overcome by some modifications to the 2000 data set and the authors would encourage ODPM to consider doing this in order to facilitate more accurate comparison between the two.

Concentrating on changes in London's retail economy, evidence of a contraction in convenience retail employment level in the capital's town centres begins to be seen as the supermarkets, located outside these areas, come to dominate the marketplace. Comparison retailing in central London appears to have fared well in competition with the retail warehouse park and shopping mall (although data are not presented on the extent and nature of these outlying centres). It is also noted that total A1 floorspace has increased in most of the capital since 1971.

The analysis should not be confined to London since it has been demonstrated here that it is possible to digitise the whole of the 1971 Census. By doing this it would be possible to start to explore some key changes in the retail sector, such as the nationwide decline in the number of bakeries and butchers, and to 
analyse the way in which the independent sector has changed.

Unpacking these trends is important, for in order to map, understand and ultimately guide where the retail economy is going (figuratively and literally) it is vital to know where it has been.

\section{Acknowledgments}

The authors would like to thank GLA Economics and in particular Matthew Waite and Margarethe Theseira for sponsoring this research. They would also like to thank David Thorpe who provided them with the hard copies of the Census and who has supported this research initiative throughout.

\section{References}

1 London Retail Consortium Statistics, http://www.brc.org.uk/lrc/statistics, accessed 18th January, 2005.

2 ODPM (2000) 'Producing boundaries and statistics for town centres: England and Wales 2000', http://www.odpm.gov.uk/stellent/groups/odpm_ planning/documents/page/odpm_plan_607875.hcsp, accessed 18th January, 2005.

3 Department of the Environment, Transport and the Regions (1998) 'Town centres: Defining boundaries for statistical monitoring, feasibility study', HMSO, London.

4 ODPM (2002) 'Producing boundaries and statistics for town centres: London Pilot Study', TSO, London.

5 Department of Industry (1975) 'Business statistics: Report in the Census of distribution and other services 1971', HMSO, London.

6 Sert, J. L. (1952) 'The heart of the city', in Tyrwhitt, J. and Sert, J. L. (eds.) 'The heart of the city', Lund Humphries, London, pp. 3-16.

7 Murphy, R. E. and Vance, J. E. J. (1954) 'Delimiting the CBD', Economic Geography, Vol. 30, pp. 189-222.

8 Thurstain-Goodwin, M. and Unwin, D. (2000) 'Defining and delineating the central areas of towns', Transactions in GIS, Vol. 4, No. 4, pp. 305-317.

9 Burrough, P. A. and Frank, A. U. (1996) 'Geographic objects with indeterminate boundaries', Taylor Francis, London.

10 ODPM (2000) op. cit.

11 Bruhns, H., private communication.

121971 and 2000 Town Centre Statistics, http://www.casa.ucl.ac.uk/towncentres.index.html.

13 Schiller, R. (2001) 'The dynamics of property location', Spon, London.

14 Camden Town on-line, http://www.camdentown.co.uk/camden8.htm, accessed 18th January, 2005. 